\title{
Kemampuan Komunikasi Matematis \\ Dalam Pendekatan Matematika Realistik \\ di Sekolah Dasar
}

\author{
Nur Fauziah Siregar \\ Institut Agama Islam Negeri (IAIN) Padangsidimpuan \\ nurfauziah125@gmail.com
}

\begin{abstract}
Mathematics has abstract objects. Students experience difficulties in mathematics because of their abstract character. The stage of the level of development of student thinking at the school level is still concrete, therefore we need an approach that is deemed good and appropriate that can overcome the problem or can bridge it with a realistic mathematical approach. This mathematics learning is oriented to experience in everyday life. Realistic Mathematics Approach in learning provides an opportunity for students to discover and reconstruct mathematical concepts, so students have an understanding of mathematical concepts. This learning can be used as an alternative to make mathematics learning more enjoyable which can affect students' mathematical communication. The mathematical communication process of good students can be a means to form effective and communicative learning, especially for elementary students who are in a concrete level of thinking.
\end{abstract}

Keywords: Mathematics Learning, Realistic Mathematics Approach, Mathematical Communication

Abstrak: Matematika memiliki objek yang bersifat abstrak. Siswa mengalami kesulitan dalam matematika karena sifat keabstrakannya. Tahap tingkat perkembangan berfikir siswa pada tingkat sekolah masih konkrit, oleh karena itu diperlukan suatu pendekatan yang dipandang baik dan tepat yang dapat mengatasi permasalahan atau dapat menjembataninya adalah dengan pendekatan matematika realistik. Pembelajaran matematika ini berorientasi pada pengalaman dalam kehidupan sehari-hari. Pendekatan Matematika Realistik dalam pembelajaran memberikan kesempatan kepada siswa untuk menemukan dan merekonstruksi konsep-konsep matematika, sehingga siswa mempunyai pemahaman tentang konsep-konsep matematika. Pembelajaran ini dapat dijadikan sebagai alternatif untuk menjadikan pembelajaran matematika lebih menyenangkan yang dapat mempengaruhi komunikasi matematis siswa. Proses komunikasi matematis siswa yang baik dapat menjadi sarana untuk membentuk pembelajaran yang efektif dan komunikatif terutama untuk siswa SD yang dalam tingkat berfikir masih konkrit.

Kata Kunci: Pembelajaran Matematika, Pendekatan Matematika Realistik, Komunikasi Matematis

Ar-Riayah : Jurnal Pendidikan Dasar vol. 3, no. 1, 2019

IAIN Curup - Bengkulu l p ISSN 2580-362X; e ISSN 2580-3611

DOI: $10.29240 /$ jpd.v3i1.864 


\section{PENDAHULUAN}

Pendidikan memiliki peran yang besar dalam mewujudkan sumber daya manusia yang berkualitas. Dengan menerapkan pendidikan yang berkualitas, maka menghasilkan sumber daya manusia yang berkualitas juga. Pendidikan mengalami pergesaran yang cukup berarti dilihat dari proses pencapaian tujuan, ilmu pengetahuan dan teknologi berkembang dengan pesat. Hal tersebut berpengaruh positif pada kualitas pendidikan yang selalu terintegritas sesuai dengan perkembangan zaman.

Pendidikan yang mampu mendukung pembangunan di masa yang akan datang adalah pendidikan yang mampu mengembangkan potensi peserta didik.1 Dalam Undang-undang Sistem Pendidikan Nasional No. 20 tahun 2003 Bab I pasal 1 menyebutkan bahwa :

Pendidikan adalah usaha sadar dan terencana untuk mewujudkan suasana belajar dan proses pembelajaran agar peserta didik secara aktif mengembangkan potensi dirinya untuk memeiliki kekuasaan spiritual keagamaan, pengendalian diri, kepribadian, kecerdasan, akhlak mulia, serta keterampilan yang diperlukan dirinya, masyarakat, bangsa dan negara.

Pada dasarnya sesuai dengan undang-undang di atas, ada suatu keharusan perubahan atau pembaharuan dalam dunia pendidikan yang dikemukakan oleh tenaga pengajar. Tenaga pengajar yang dapat menggarahkan siswa, kemana pengetahuan yang diperoleh utuk diimplementasikan. Untuk dapat menciptakan hal yang demikian tenaga pengajar harus dapat merencanakan pengelolaan pendidikan dengan baik.

Dalam kehidupan sehari-hari, matematika merupakan salah satu pelajaran yang sangat penting, karena sebagian besar aktivitas kehidupan bersinggungan dengan matematika. Matematika juga sangan diperlukan dalam menghadapi kemajuan IPTEK. Hal ini senada dengan pendapat Soedjadi yang menyatakan bahwa matematika sebagai salah satu ilmu dasar, baik aspek terapannya maupun aspek penalarannya mempunyai peranan yang penting dalam penguasaan ilmu dan teknologi.2 Oleh karena itu, salah satu cara untuk meningkatkan sumber daya manusia yang berkualitas melalui pendidikan matematika.

1 Badar, T. I. Mendesain model pembelajaran inovatif, progresif dan kontekstual. (Jakarta: Prenadamedia group. 2003). 1-2

2 Soedjadi, R., Kita Pendidikan Matematika di Indonesia. Direktorat Jenderal Pendidikan Tinggi Departemen Pendidikan Nasional. (2000). 18 
Pembelajaran matematika pada saat ini diarahkan untuk mempersiapkan aktivitas-aktivitas yang bermanfaat untuk siswa dalam belajar, yang mengalihkan paradigma lama ke paradigma baru. Siswa yang aktif dalam pembelajaran matematika harus didukung dengan menyediakan media dan bahan ajar yang menunjang aktivitas-aktivitas belajar. Siswa diharapkan dapat memiliki "doing math" yang dapat menemukan dan membangun pengetahuan matematika siswa.

Salah satu kemampuan matemaika yang sering dipergunakan dalam kehidupan sehari-hari adalah komunikasi matematik. Hal tersebut dapat dilihat dari NCTM merekomendasikan lima kompetensi standar yang utama yaitu kemampuan pemecahan masalah (Problem Solving), kemampuan komunikasi (Communication), kemampuan koneksi (Connection), kemampuan penalaran (Reasoning), dan representasi (Representation).3 Dalam pembelajaran matematika, siswa harus dapat menerapkan komunikasi matematik melalui mengungkapkan gagasan atau ide-ide matematika. Gagasan tersebut dapat disajikan baik dalam bentuk lisan dan tulisan. Bentuk secara lisan dapat digambarkan dengan kemampuan siswa berkomunikasi dan memaparkan pengetahuan yang dimiliki didepan siswa lainnya. Sedangkan untuk yang bentuk tulisan dapat berupa menuliskan simbol-simbol dalam model matematika, gambar-gambar dan objek lainnya.

Komunikasi matematika merupakan bagian yang penting dalam kegiatan belajar matematika. Hal ini sejalan dengan Permen 22 Tahun 2006 tentang Standar Kompetensi Kelulusan dalam bidang matematika, komunikasi matematis merupakan salah satu aspek yang harus dimiliki dan dikembangkan dalam pembelajaran matematika. Dengan komunikasi matematika, siswa dapat mengorganisasi berpikir matematikanya.

Menurut Ontario bahwa berkomunikasi matematika adalah menyampaikan makna melalui lisan, ditulis, dan bentuk visual (misalnya, memberikan penjelasan alasan atau pembenaran hasil secara lisan atau tertulis; mengkomunikasikan ide-ide matematika dan solusi secara tertulis, dengan menggunakan angka dan simbol aljabar, dan secara visual, menggunakan gambar, diagram, grafik, tabel, grafik, dan materi konkret).4 Untuk mewujudkan siswa dapat berkomunikasi matematik baik secara lisan dan tulisan dibutuhkan suatu pembelajaran matematika yang berbasis komunikasi. Pembelajaran yang

3 National Council of Teacher Mathematics. Principles and Standards for Schools Mathematics. USA. Reston. V.A. (2000).

4 Ontario Ministry of Education's. The Ontario Curriculum, Grades 1-8: Mathematics. Ontario: Queen's Printer for Ontario, (2005). 20 
baik merupakan suatu pembelajaran yang dapat mengantarkan siswa aktif, kreatif, inovatif dan menyenangkan, sehingga tercapainya komunikasi matematik siswa. Salah satu alternatif pembelajaran matematika yang sesuai dengan perubahan dalam pembelajaran dan banyak mengungkapkan komunikasi matematik adalah Pembelajaran Matematika Realistik.

Untuk merealisasikan pembelajaran matematika realistik, menurut Saragih diperlukan suatu pengembangan materi pembelajaran matematika yang dekat dengan kehidupan siswa, sesuai dengan tahap berpikir siswa, serta metode evaluasi yang terintegrasi pada proses pembelajaran yang tidak hanya berujung pada tes akhir.5 Pembelajaran yang dekat dengan kehidupan siswa mendekati dengan pembelajaran realistik, sesuai dengan kata 'realistis' koneksi dengan dunia nyata. Dunia nyata yang dimaksud bukan hanya dapat dilihat akan tetapi situasi yang nyata dalam siswa pikiran.

Dalam hasil penelitian Haji yang dilaksanakan di kelas III SDPN Setia budi UPI, diperoleh hasil bahwa dengan pembelajaran matematika realistik memberikan pengaruh yang signifikan terhadap hasil belajar matematika di Sekolah Dasar.6 Demikian pula, Saragih dalam disertasinya menemukan bahwa kemampuan berpikir logis dan kemampuan komunikasi matematika siswa SMP yang diajar dengan PMR ternyata lebih baik dibandingkan siswa SMP yang diajar dengan cara biasa.7 Beberapa penelitian tersebut di atas telah menunjukkan dampak positif dari penerapan PMR di sekolah.

Dalam PMR siswa dibimbing untuk dapat menarik kesimpulan bagi masing-masing siswa sehingga mengantarkan pembelajaran tersebut bermakna. Hal itu dipertegas oleh Asmin bahwa agar pembelajaran bermakna bagi siswa maka pembelajaran seyogianya dimulai dengan masalah-masalah yang realistik. 8 Pengalaman belajar yang diperoleh siswa melalui penyelesaian masalah, dengan cara mencari dan menemukan sendiri dengan skema yang dimiliki dalam pikirannya mengantarkan siswa tidak mudah melupakan yang dipelajarinya. Hal tersebut menunjukkan dengan PMR tidak hanya memberikan pengetahuan,

5 Saragih, S. Mengembangkan Kemampuan Berpikir Logis dan Komunikasi Matematik Siswa Sekolah Menegah Pertama melalui Pendekatan Matemaatika Realistik. Disertasi. Bandung: Program Pascasarjana UPI Bandung. (2007).

6 Haji. Pengaruh Pendekatan Matematika Realistik Terhadap Hasil Belajar Matematika di Sekolah Dasar. Disertasi UPI Bandung. (2005).

7 Op.Cit

8 Asmin. Implementasi Pembelajaran Matematika Realistik dan Kendala yang Muncul di Lapangan. (2007). (Online).(http://www.depdiknas.go.id/jurnal/44/asmin. htm 
mengantarkan siswa untuk bertanya baik antar siswa dengan siswa dan siswa dengan guru serta membentuk siswa yang bersikap sosial.

PMR dilihat dari filosofinya merupakan matematika dekat dengan situasi kehidupan setiap hari-hari. Konteks masalah-masalah sehari - hari secara tekhnik membuka ruang untuk mengantarkan siswa untuk berkomunikasi baik tulisan dan lisan. Masalah yang kontekstual dengan mengubah atau memodelkan matematika menggunakan angka dan simbol aljabar, menggunakan gambar, diagram, grafik, dan tabel. Dengan lisan siswa memberikan alasan pembenaran hasil dan dapat juga memberikan penjelasan dari benda-benda nyata yang dijadikan objek dalam pembelajaran.

\section{LANDASAN TEORI}

\section{Kemampuan Komunikasi Matematis}

Komunikasi berasal dari bahasa Latin Communication yang diturunkan dari kata communis yang artinya membuat kebersamaan atau membangun kebersamaan antara dua orang atau lebih. Akar kata communis adalah communico yang artinya berbagi, dalam hal ini yang dibagi adalah pemahaman bersama melalui pertukar pesan.9 Penyampaian pesan untuk memberitahukan sesuatu, baik itu ide-ide ataupun gagasan secara lisan dan tulisan merupakan definisi komunikasi secara umum. Sedangkan definisi dari komunikasi matematis merupakan suatu kemampuan/keterampilan siswa dalam menyampaikan ide-ide atau gagasan matematika yang dapat ditafsirkan secara tertulis dalam menyelesaikan masalah.

Pentingnya komunikasi dalam pembelajaran matematika sebagaimana tercantum dalam Kurikulum "Nasional 2006" yang berbasiskan sesuai tingkat satuan pendidikan baik untuk tingkat SD, SMP maupun SMA juga mengedepankan kemampuan komunikasi matematika sebagai salah satu kemampuan dasar yang perlu dimiliki siswa. Menurut Baroody, bahwa pembelajaran harus dapat membantu siswa mengkomunikasikan ide matematika melalui lima aspek komunikasi yaitu representing, listening, reading, discussing dan writing.10 Ke lima aspek ini memiliki keterkaitan yang kuat dalam proses belajar yang meningkatkan interaksi antar siswa dengan guru dan siswa dengan siswa.

9 Dani Vardiansyah, Filsafat Ilmu Komunikasi "Suatu Pengantar" (Jakarta: PT.Indeks, 2008). 24.

10 Baroody. A.J. Problem Solving, Reasoning, and Communicating. (New York: Macmillan Publishing, 1993). 107 
Bansu Ansari menyatakan bahwa komunikasi matematika terdiri atas komunikasi lisan (talking) dan tulisan (writing), komunikasi lisan diartikan sebagai suatu interaksi yang ada dalam suatu lingkungan kelas dimana terjadi pengalihan pesan berisi tentang materi matematik yang sedang dipelajari dan komunikasi tulisan diartikan sebagai kemampuan atau keterampilan siswa dalam menggunakan kosakatanya, notasi, dan struktur matematik baik dalam bentuk penalaran, koneksi, maupun dalam problem solving.11 Seseorang yang memiliki kemampuan komunikasi tulisan belum tentu bisa mengkomunikasikan secara lisan, begitu juga sebaliknya. Oleh karena itu, siswa yang memiliki kemampuan komunikasi, harus memiliki dua unsur penting yaitu berbicara dan menulis. Ke dua kemampuan komunikasi tersebut merupakan kemampuan komunikasi matematis.

Kemampuan komunikasi matematika siswa dalam pembelajaran, NCTM menguraikan beberapa indikator yang dapat mengukur kemampuan komunikasi matematika siswa, sebagai berikut:

a) Kemampuan mengekspresikan ide-ide matematis melalui lisan, tulisan, dan mendemonstrasikannya serta menggambarkannya secara visual.

b) Kemampuan memahami, mengiterpretasikan, dan mengevaluasi ide-ide matematis baik secara lisan, tulisan, maupun dalam bentuk visual lainnya.

c) Kemampuan dalam menggunakan istilah, notasi matematika dan struktur-strukturnya untuk menyajikan ide-ide, menggambarkan hubungan-hubungan dengan model-model situasi.12

Siswa belajar matematika dengan berbicara dan menulis tentang apa yang kerjakan pada proses pembelajaran, dengan cara mengungkapkan ide-ide dan gagasan dan mendengarkan siswa lain dalam berbagi ide dan strategi dari masalah matematika yang diberikan. Berkomunikasi dalam matematika dinyatakan jika siswa mampu menyatakan dan menafsirkan ide-ide matematika secara lisan dan tulisan baik dengan menggambarkan simbol-simbol, gambar, tabel dan grafik, serta bekerja sama dalam diskusi mengutarakan ide-ide dalam proses belajar matematika.

\section{Pendekatan Matematika Realistik}

11 Bansu I Ansari, Komunikasi Matematik Konsep dan Aplikasi (Banda Aceh:Pena, 2009). 11.

12 Iis Sri Elia R, Komunikasi Dalam Pembelajaran Matematika. Prossiding, Volume 1, No. 2, (2014). 153 
Pendekatan matematika realistik pada dasarnya diperkenalkan dan dikembangkan oleh Institut Freudenthal di Belanda, yang dikenal dengan nama Realistics Mathematics Education (RME). Pendekatan matematika realistik merupakan salah satu pendekatan yang berorientasi pada matematisasi kehidupan sehari-hari. Pembelajaran matematika dengan pendekatan matematika realistik berlandaskan matematika adalah aktivitas siswa dalam belajar. Soedjadi (dalam Usdiyana) yang menyatakan Freudenthal berpendapat bahwa matematika merupakan kegiatan manusia yang lebih menekankan aktivitas siswa untuk mencari, menemukan, dan membangun sendiri pengetahuan yang diperlukan sehingga pembelajaran menjadi terpusat pada siswa.13

Siswa diberikan kesempatan untuk menemukan sendiri kembali ide atau konsep matematika dengan arahan dan bimbingan guru melalui persoalan dunia nyata merupakan karakteristik dari pendekatan matematika realistik. Proses pengembangan konsep dan ide-ide matematika yang dimulai dari dunia nyata oleh De Lange (dalam Usdiyana) disebut matematisasi konsep dan memiliki model skematis proses belajar seperti gambar berikut:14

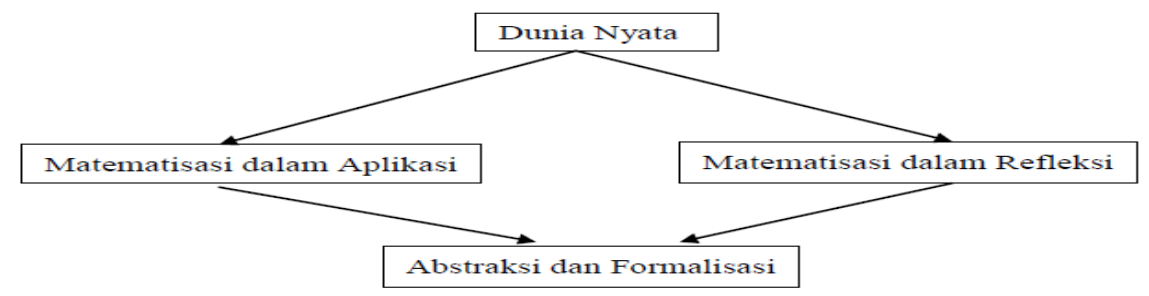

\section{Gambar. 1 : Model Skematis Proses Matematisasi Konsep}

Gambaran proses pengembangan konsep menunjukkan bahwa proses lebih penting dari hasil akhir. Pengetahuan merupakan proses transformasi secara terus menerus dibentuk dan dibentuk kembali yang tidak berujung yang menunjukkan proses lebih diutamakan. Pada dasarnya proses pencapaian pembelajaran menekankan pada konsep yang sudah dikenal atau diketahui siswa, setiap siswa memiliki konsep awal tentang ide-ide matematika. Pembelajaran yang terbentuk merupakan pembelajaran yang bermakna.

Graveimejer (dalam Usdiyana) mengemukakan tiga prinsip utama dalam pendekatan matematika realistik yaitu : (1) Penemuan terbimbing dan

13 Usdiyana, D. dkk. Meningkatkankemampuan Berpikir Logis Siswa SMP Melalui Pembelajaran Matematika Realistik. Jurnal Pengajaran MIPA. Vol. 13. No.1. Edisi April (2009).

14 Ibid 
Bermatematika secara Progressif (Guided Reinvention and Proggressive Mathematization), (2) Penomena Pembelajaran (Didactical Phenomenology) dan (3) Pengembangan Model Mandiri (Self Developed Models). 15 Penemuan terbimbing, siswa diberi kesempatan untuk menemukan sendiri konsep matematika melaui soal kontekstual. Bermatematika secara progressif dimaksud bermatematika secara horizontal dan vertikal.

Matematisasi horizontal, diawali dengan soal-soal kontekstual, mencoba menguraikan dengan bahasa dan simbol yang dibuat siswa sendiri, dan menyelesaikan soal tersebut. Sedangkan matematisasi vertikal merupakan suatu kegiatan pada saat memformulasikan suatu masalah ke dalam berbagai penyelesaian masalah matematika dengan menerapkan aturan matematika. Dengan matematisasi vertikal, siswa melakukan kegiatan dengan menyatakan suatu hubungan dengan suatu formula, membuktikan keteraturan, merumuskan konsep dan melakukan generalisasi.

Tarigan menyatakan ada lima karakteristik PMR, yaitu: menggunakan masalah kontekstual, menggunakan model, kontribusi siswa, kegiatan interaktif, keterkaitan materi.16 Kelima karakteristik tersebut wajib terlihat pada pendekatan matematika realistik.

Masalah kontektual dalam PMR merupakan suatu titik awal untuk menemukan dan mengembangkan ide dan konsep matematika. Konteks merujuk kepada masalah yang nyata dalam situasi pikiran dan hubungan dengan dunia nyata. Menggunakan model berkaitan dengan model matematika yang dibangun sendiri oleh siswa. Model matematika merupakan jembatan bagi siswa untuk membentuk sendiri model-model dari situasi nyata ke dalam bentuk abstrak. Kontribusi siswa mengantarkan siswa aktif mengkontruksikan sendiri bahan matematika dengan bimbingan guru. Kesempatan diberikan seluasluasnya kepada siswa untuk mengembangkan berbagai strategi yang dapat mengarahkan pada pengkontruksian procedural matematika untuk memecahkan masalah. Adapun Bentuk-bentuk interaksi dapat berupa diskusi, penjelasan, persetujuan, pertanyaan yang digunakan untuk mencapai bentuk pengetahuan matematika formal yang ditemukan sendiri oleh siswa. Keterkaitan atau pengintegrasian antar materi pelajaran perlu dieksplorasi untuk mendukung pembelajaran agar lebih bermakna. Dengan pengintegrasian memudahkan siswa untuk memecahkan masalah.

15 Ibid

16 Tarigan. D. Pemebelajaran Matematika Realsitik..( Jakarta : Departemen Pendidikan Nasional Direktorat Jenderal Pendidikan Tinggi, 2006) 
Penggunaan pendekatan matematika relaistik adalah proses pembelajaran matematika yang sesuai dengan karakteristik dan prinsip-prinsip pembelajaran realisik. Adapun langkah-langkah dalam kegiatan pendekatan matematika realistik tergambar pada tabel berikut:

\section{Tabel 1. Langkah-Langkah Pendekatan Matematika Realistik}

\begin{tabular}{|c|c|}
\hline Aktivitas Guru & Aktivitas Siswa \\
\hline \multicolumn{2}{|c|}{ Langkah 1. Memahami masalah kontekstual } \\
\hline $\begin{array}{l}\text { Mengkondisikan kelas agar } \\
\text { dapat berlangsung suasana } \\
\text { pembelajaran yang kondusif } \\
\text { serta melakukan apersepsi dan } \\
\text { motivasi dengan } \\
\text { menyampaikan tujuan dan } \\
\text { kegunaan dalam mempelajari } \\
\text { materi. } \\
\text { - Memberikan masalah } \\
\text { kontekstual kepada siswa } \\
\text { yang telah disusun dalam LAS } \\
\text { Sebagai fasilitator guru } \\
\text { memberikan bantuan pada } \\
\text { siswa memahami masalah } \\
\text { kontekstual }\end{array}$ & $\begin{array}{l}\text { - Siswa mempersiapkan diri untuk belajar } \\
\text { sehingga tercapai pembelajaran yang } \\
\text { kondusif. Siswa mengingat materi prasyarat } \\
\text { dan mendengarkan penjelasan guru tentang } \\
\text { tujuan dan kegunaan mempelajari materi } \\
\text { - Menerima dan memahami masalah } \\
\text { kontekstual } \\
\text { Mencermati bantuan guru sehingga siswa } \\
\text { mampu memahami masalah }\end{array}$ \\
\hline
\end{tabular}

\section{Langkah 2. Meyelesaikan masalah kontekstual}

- Guru membantu dan menyempurnakan hasil kegiatan siswa dengan cara mengajukan pertanyaan untuk mengarahkan siswa mengkontruksi pengetahuannya tentang kemungkinan model of yang sesuai Langkah 3. Membandingkan atau mendiskusikan jawaban

- Guru berkeliling kelompok yang satu ke kelompok yang lain melakukan interaksi dengan siswa sambil mengamati dan memberi dorongan untuk menyelesaikan soal.

- Meminta satu kelompok siswa untuk menyajikan model of dan cara penyelesaian soal di depan kelas
- Siswa secara berkelompok merumuskan model of dan cara penyelesaian dari masalah kontekstual
- Siswa berdiskusi dengan teman sekelompoknya, melakukan negosiasi atas jawaban masing-masing

- Siswa meyajikan model of dan cara penyelesaian soal di depan kelas.

- Satu orang siswa yang lain meyajikan model 
- Memberi kesempatan pada

of yang berbeda

kelompok siswa yang lain untuk menyajikan model of lain yang berbeda.

- Menaggapi hasil jawaban teman yang ada di

- Memberi kesempatan pada siswa untuk menanggapi dan memilih model of yang sesuai dan benar papan tulis dan mendiskusikan hasil kerja antar siswa

- Mendengarkan dan menanggapi penjelasan guru

- Guru melakukan negosiasi, intervensi kooperatif, penjelasan, refleksi dan evaluasi untuk membimbing siswa hingga sampai memahami konsep matematika formal

\section{Langkah 4. Menyimpulkan}

- Guru mengarahkan siswa membuat rangkuman dan kesimpulan, serta melakukan refleksi terhadap materi yang sudah dipelajari, menilai kelemahan dan kelebihan yang ada pada diri mereka masing-masing, dan mencari jalan keluar untuk mengurangi

- Siswa membuat rangkuman dan atau menghilangkan kelemahan dirinya ketika mempelajari matematika.

Sumber : Risna Mila Bela 17

\section{PENDEKATAN MATEMATIKA REALISTIK DALAM PEMBELAJARAN}

Kreativitas guru dibutuhkan dalam merencanakan pembelajaran untuk menciptakan pembelajaran menyenangkan yang menjadikan pembelajaran lebih bermakna. Untuk itu harus ada upaya yang dilakukan guru untuk meningkatkan kualitas pembelajaran matematika. Memperoleh kualitas hasil pembelajaran

17 Risna Mira Bella Saragih. Peningkatan Kemampuan Pemecahan Masalah Matematika Siswa Melalui Pendekatan Matematika Realistik. Tesis. (Medan : Program Pascasarjana Universitas Negeri Medan, 2011). 29 
matematika yang baik disebabkan dari beberapa faktor. Salah satu faktor yang mempengaruhi adalah penggunaan model penyajian materi tersebut.

Dalam pembelajaran matematika sebaiknya diawali dengan menyajikan masalah yang kontekstual. Masalah yang diberikan merupakan masalah yang berhubungan dengan kehidupan sehari-hari siswa dan akan lebih baik dengan memberikan masalah yang nyata berada dihadapan siswa. Berikut tahapan PMR dalam pembelajaran matematika dengan menyajikan soal komunikasi matematis:

1. Memahami masalah kontekstual

Guru memberikan masalah kontekstual yang terlampir dalam LKS yang diberikan kepada siswa dalam kelompok berdiskusi. Kegiatan siswa dengan memahami masalah tersebut. Menggunakan konstektual merupakan karakteristik dari PMR yang menyajikan ke matematika formal sampai ke pembentukan konsep.

Masalah Kontekstual dengan Kemampuan Komunikasi Matematis:

Tania mempunyai sebuah kue yang berbentuk bulat yang akan dibagikan kepada 3 orang temannya. Berapa bagian yang diperoleh Tania dengan 3 orang temannya?

(Guru menugaskan kepada kelompok siswa untuk memotong kue tersebut menjadi bagian yang sama dan meminta siswa untuk menggambarkanya dalam lembaran yang disediakan atau LKS)

Penyelesaian.

Siswa akan memperoleh 4 bagian yang sama yaitu $\frac{1}{4}$ bagian dari kue tersebut.

Siswa mampu menjelaskan " Pecahan $\frac{1}{4}$ mewakili ukuran masing-masing potongan kue. Banyaknya potongan yang sama ada 4 , maka penyebut dari pecahan tersebut adalah 4, sedangkan 1 adalah menunjukkan bagian kue yang dimakan Tania dan temannya yang disebut sebagai pembilang."

Dilihat dari masalah yang diberikan siswa akan mencapai tingkat kemampuan komunikasi matematis karena merujuk dari indikator tulisan dan lisan. Tulisan yang dimaksud, siswa dapat mengungkapkan idenya dengan membuat gambar kue secara utuh dan potongan kue yang diminta dari soal. Sedangkan dengan cara lisan, siswa mampu menjelaskan hasil penyelesaian yang $\frac{1}{4}$.

2. Menyelesaikan masalah kontekstual

Siswa yang mengalami kesulitan dalam menyelesaikan masalah, maka guru menjelaskan situasi dan kondisi dari soal. Guru memberikan petunjuk- 
petunjuk seperlunya terhadap yang belum dipahami oleh siswa, dengan memberikan penjelasan sampai siswa mengerti maksud dari soal.

Dengan menggunakan lembaran kerja, siswa mengerjakan soal dengan cara mereka sendiri dengan tingkat kesulitan soal yang berbeda. Guru memberikan motivasi pada proses menyelesaikan masalah dengan cara pemberian petunjuk. Pada tahap ini, muncul dari prinsip pendekatan matematika realistik yaitu prinsip self developed models. Dengan karakteristik pendekatan matematika realistik yaitu menggunakan model.

3. Membandingkan dan mendiskusikan jawaban

Memberikan kesempatan kepada siswa untuk membandingkan dan mendiskusikan hasil jawaban secara berkelompok, dan dilanjutkan dengan membandingkan (memeriksa dan memperbaiki). Pada tahap ini siswa dilatih untuk mengeluarkan ide, yang merupakan suatu kontribusi siswa dalam berinteraksi antar siswa dengan siswa, siswa dengan guru dan siswa dengan sarana prasarana.

4. Menyimpulkan

Mengarahkan siswa untuk menarik kesimpulan suatu konsep atau prosedur. Karakteristik pendekatan matematika realistik dalam langkah ini adalah interaksi antara siswa dengan guru sebagai pembimbing.

Pendekatan matematika realistik adalah suatu pendekatan yang diterapkan dalam pembelajaran matematika. Proses pembelajaran yang bertitik tolak dari hal-hal yang real bagi siswa merupakan suatu pembelajaran yang bermakna, dengan aktivitas siswa yang menemukan kembali dan mengkonstruksi pengetahuan dengan konsep sendiri. Selanjutnya dilakukan tindakan dengan diaplikasikan yang menekankan dalam keterampilan process of doing mathematics' proses PMR memenuhi karakteristik berikut : (1) menggunakan masalah kontekstual, (2) menggunakan model yang sesuai dengan materi pelajaran (3) menggunakan kontribusi siswa, (4) interaktif, dan (5) menggunakan keterkaitan (intertwinment).

\section{KESIMPULAN}

Salah satu pendekatan yang membawa dan menumbuh kembangkan kompetensi siswa dalam komunikasi matematis ke dalam pembelajaran serta siswa secara aktif dalam pembelajran adalah pendekatan Matematika Realistik (RME). Pendekatan Matematika Realistik adalah suatu pendekatan yang menempatkan pengalaman siswa berdasarkan realitas yang diberikan yang 
merupakan suatu titik awal pembelajaran melalui masalah kontekstual. Dengan masalah realitas atau masalah kontekstual yang ada dapat memberikan kesempatan kepada siswa untuk dapat mengkonstruksi sendiri pengetahuan matematika formalnya. Dengan pendekatan ini siswa mudah menguasai konsep, pendekatan ini dalam pembelajaran menggunakan konteks yang merupakan titik awal pembangunan konsep matematika yang menciptakan kemampuan komunikasi matematis. Penggunaan konteks dapat membangun kreativitas siswa. Konfirmasi dalam pembelajaran merupakan suatu kegiatan yang dibutuhkan untuk mendapatkan informasi. Komunikasi adalah inti dari konfirmasi, dimana siswa mengkomunikasikan ide-ide dan gagasan baik secara lisan dan tulisan. Masalah kontekstual atau realitas yang ada dapat dikomunikasikan siswa kedalam bentuk, skema, gambar, grafik dan mengubah masalah ke dalam model matematika yang merupakan bentuk dari komunikasi matematis. Sedangkan dalam komunikasi matematis secara lisan dapat dilihat pada proses komunikasi yang baik antara siswa dengan siswa dan guru yang dapat membantu menyelesaikan masalah. Kemampuan siswa dalam mempresentasikan hasil penyelesaian masalah merupakan bentuk secara lisan.

\section{DAFTAR PUSTAKA}

Asmin. Implementasi Pembelajaran Matematika Realistik dan Kendala yang Muncul di Lapangan.(2007).(Online).(http://www.depdiknas.go.id/jurnal/44/asmi n. htm

Badar, T. I. Mendesain model pembelajaran inovatif, progresif dan kontekstual. (Jakarta: Prenadamedia group. 2003).

Bansu I Ansari, Komunikasi Matematik Konsep dan Aplikasi (Banda Aceh:Pena, 2009)

Baroody. A.J. Problem Solving, Reasoning, and Communicating. (New York: Macmillan Publishing, 1993).

Dani Vardiansyah, Filsafat Ilmu Komunikasi "Suatu Pengantar" (Jakarta: PT.Indeks, 2008).

Haji. Pengaruh Pendekatan Matematika Realistik Terhadap Hasil Belajar Matematika di Sekolah Dasar. Disertasi UPI Bandung. (2005).

Iis Sri Elia R, Komunikasi Dalam Pembelajaran Matematika. Prossiding, Volume 1, No. 2, (2014).

National Council of Teacher Mathematics. Principles and Standards for Schools Mathematics. USA. Reston. V.A. (2000). 
96| Ar-Riayah : Jurnal Pendidikan Dasar Vol. 3, No. 1, 2019

Ontario Ministry of Education's. The Ontario Curriculum, Grades 1-8: Mathematics. Ontario: Queen's Printer for Ontario, (2005).

Risna Mira Bella Saragih. Peningkatan Kemampuan Pemecahan Masalah Matematika Siswa Melalui Pendekatan Matematika Realistik. Tesis. (Medan : Program Pascasarjana Universitas Negeri Medan, 2011).

Saragih, S. Mengembangkan Kemampuan Berpikir Logis dan Komunikasi Matematik Siswa Sekolah Menegah Pertama melalui Pendekatan Matemaatika Realistik. Disertasi. (Bandung: Program Pascasarjana UPI Bandung. 2007).

Soedjadi, R., Kita Pendidikan Matematika di Indonesia. Direktorat Jenderal Pendidikan Tinggi Departemen Pendidikan Nasional. (2000).

Tarigan. D. Pemebelajaran Matematika Realsitik...( Jakarta : Departemen Pendidikan Nasional Direktorat Jenderal Pendidikan Tinggi, 2006)

Usdiyana, D. dkk. Meningkatkankemampuan Berpikir Logis Siswa SMP Melalui Pembelajaran Matematika Realistik. Jurnal Pengajaran MIPA. Vol. 13. No.1. Edisi April (2009) 